\title{
Attitude towards Mobile Advertising and Mobile Web Information Acquisition Behaviour: Perspectives from the Advertising Value, Credibility and Self-efficacy
}

\author{
Ling Qin \\ School of Management \\ Wuhan University of Science and Technology \\ Wuhan, People's Republic of China
}

\author{
Hong Yan \\ School of Management \\ Wuhan University of Science and Technology \\ Wuhan, People's Republic of China
}

\begin{abstract}
Mobile e-commerce is booming in China, of which mobile advertising is one of the key applications. Despite the rapid growth, the effect of mobile advertising is generally considered poor because of the low click rate and and low users' information acquisition rate about products and services. The purpose of this paper is to explore the formation of customers' attitude towards mobile advertising (ATMA) and the further impact exerted by customers' attitude and self-efficacy on their mobile web information acquisition behavior. The survey data collection was conducted and the partial least squares (PLS) structured equation modelling (SEM) was employed to verify the research model. The results show that perceived informativeness, perceived entertainment and credibility were significant predictors of ATMA, but on which the effect of perceived irritation is not significant. ATMA was found to be a significant positive predictor of mobile advertising usage for getting information on which the effect of self-efficacy on is weaker. The paper theoretically extends the current body of knowledge on mobile advertising by exploring the impact of ATMA and selfefficacy on consumers' mobile web information acquisition behavior and practically contributes influential factors for effective advertising to marketers and advertisers.
\end{abstract}

Keywords-mobile advertising; advertising value; credibility; mobile advertising usage behavior; self-efficacy

\section{INTRODUCTION}

With the rapid spread of mobile terminals, especially the smart phones, advertising mediums have undergone great changes. Mobile advertising is becoming the most important form of advertising in China, which can be an extremely promising advertising market. Mobile advertisement plays an increasing role in the decision-making process in helping customer purchases.

Attitude towards advertising has long been considered an important factor in predicting the effectiveness of advertising (Lutz, MacKenzie, and Belch 1983) [1]. Ducoffe (1995) [2] stated that advertising value is a measure of advertising effectiveness, which can usefully explain the formation of attitude towards web advertising. Because of the sophisticated mobile Web features and popularity of smartphones and empowered customers, Ducoffe's advertising value model also provides an understanding of the underlying process of how mobile advertisements influence customer's attitude towards mobile advertising in the context of mobile advertisements.

Even though prior studies on mobile advertising have examined cognitive, affective, and economic factors as predictors of attitude toward mobile advertising or intention to purchase (Blanco et al., 2010) [3], few studies explained a process for how attitude toward mobile advertising influence consumers' mobile web information acquisition behavior.

The research questions of this study are as follows: for advertising value and credibility, which one is more important to predict ATMA? Does ATMA impact mobile web advertising usage behavior? Does self-efficacy impact mobile web advertising usage behavior?

This study explores the formation of ATT from the perspectives of advertising value and credibility, which we think provides a new view for mobile advertising research and practice alike, and is critical for employing mobile advertising strategy effectively. Following this introduction, we review the literature, focusing on advertising value, credibility of advertising, attitude towards mobile advertising and selfefficacy. Then, we develop the research model and hypotheses, describe the research methodology and provide the results of the research and a discussion of these results. Finally, we discuss the implications for theory and practice.

\section{LITERATURE REVIEW}

\section{A. Advertising Value}

Advertising value can be seen as an overall representation and assessment of the worth of advertising (Zha, X., et al. 2014). In Ducoffe's model (1995) [2], perceptions of informativeness, entertainment and irritation as predictors of advertising value are suggested which in turn influence attitude toward advertising. Informativeness refers to the extent to which the advertising message includes informational contents (Aaker \& Norris, 1982) [4]. Entertainment denotes the ability to fulfill consumers' needs for diversion, esthetic enjoyment or 
emotional release (McQuail, 2005) [5]. Irritation in a commercial is one that is provoking, causing displeasure and momentary impatience (Aaker \& Bruzzone, 1985) [6]. Irritation can be defined as the extent to which the advertising message is messy and irritating to consumers. Despite prior researches have applied Ducoffe's advertising model in various contexts such as the Web, studies did not adopt the advertising model in the context of smartphone advertisements.

\section{B. Credibility of Advertising}

Advertising credibility refers to "consumers' perception of the truthfulness and believability of advertising in general" (MacKenzie and Lutz 1989) [7]. Credibility is critical for the formation of attitude towards mobile advertising and also has a major impact on online buying patterns (Goldfarb and Tucker 2011) [8]. The virtual Internet makes it more difficult to build advertising credibility (McKnight and Kacmar 2006) [9] especially in mobile web context which has led to a host of recent credibility studies.

\section{Attitude towards Mobile Advertising}

Attitude is critical for explaining people's behaviors. In a study conducted by Wong and Tang (2008) [10] it was determined that the attitude and intention towards mobile advertising were generally negative. Along with this, it was also determined that the entertainment factor had the strongest effect on attitude and there was no important relationship between permission factor and attitude [10]. As a result of the study conducted by the researchers in Taiwan, it was determined that consumers were generally in a negative attitude towards mobile advertisements but developed positive attitudes when they were asked for permission.

\section{Self-Efficacy}

Self-efficacy was defined as individuals' judgments of their capabilities to execute courses of action required to deal with prospective situations and attain designated types of performances (Bandura, 1977, 1982) [11, 12]. People with a higher level of self-efficacy perceptions have more confidence in their actions. They are willing to exert more effort to overcome difficulty and failure, full of patience, perseverance, energy and resilience (Ren, 2000) [13]. This study examines self-efficacy in getting information, which is defined as individuals' judgments of their own capabilities to search, compare and evaluate product information they need from mobile advertising (Pavlou and Fygenson, 2006) [14].

\section{DEVELOPMENT OF RESEARCH MODEL}

The purpose of this paper is to explore the formation of consumers' attitude towards mobile advertising and its facilitating role in mobile web information acquisition behavior, from the perspectives of advertising value and credibility. The research model is based on the premise that perceived informativeness, perceived entertainment, perceived irritation, and credibility of mobile advertising influence the consumers' attitude towards mobile advertising. Mobile advertising usage for getting information is modeled as the consequence of consumers' attitude towards mobile advertising. The model also highlights the influence of self-efficacy on the consumers' behavior of mobile advertising usage. The complete research model is presented in Figure 1.

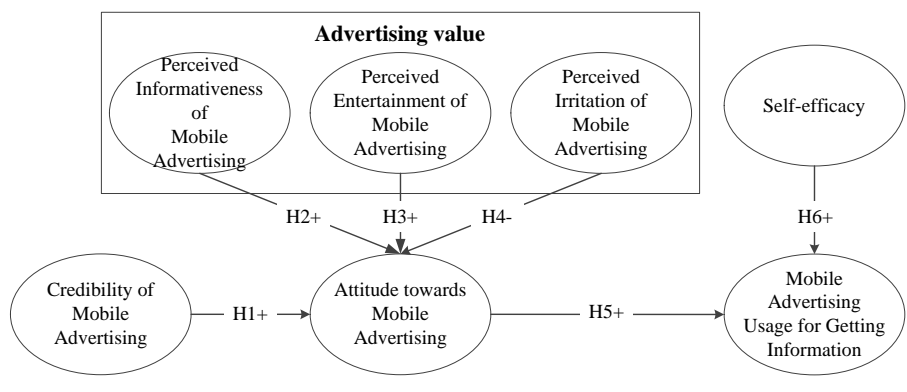

Fig. 1. Research model.

\section{A. Credibility of Mobile Advertising}

Credibility of an advertisement refers to the perceived truthfulness and believability of advertising (MacKenzie \& Lutz, 1989) [9]. Advertising credibility has been found to have a direct positive effect on the evaluation of customers (Choi et al., 2002) [15]. Credible advertising sources can 'influence opinions, attitudes, and/or behavior' (Lafferty and Goldsmith, 1999) [16]. Haghirian, Madlberger, and Tanuskova (2005) [17] confirm that credibility of message content will positively affect consumers' assessment of mobile advertising. Based on prior studies in the mobile advertising context, we posit that the credibility of mobile advertisements has a positive effect on the consumers' attitude towards mobile advertising. Hence, we hypothesize:

H1: Credibility of mobile advertising (CMA) has a positive relationship with attitude towards mobile advertising (ATMA).

\section{B. Advertising Value}

Ducoffe (1995) [2] identified the primary benefits and costs consumers derive from advertising, and confirm the respective roles of informativeness, entertainment, and irritation as important predictors of the value of advertising.

The informativeness dimension is the ability of advertisements to provide updated, timely, and easily accessible information. Quality of information of a company in a mobile advertisement has a direct effect on the consumers' perceptions related to the company and its products. Information that is sent to consumers via mobile devices should be correct, sent on time, and provide benefits to consumers. The informativeness of mobile advertisement messages positively influences perceived advertising value.

Bauer and Greyer (1968) [18], Pollay and Mittal (1993) [19], in their studies, found out that hedonic pleasure had positive effects on attitudes towards advertisements. A high degree of enjoyment during interaction with computer-based media leads to positive affect and mood of the customer (Hoffman \& Novak, 1996) [20]. Entertainment services may also increase value for the customer in mobile advertisements. Entertainment expresses consumers' sense of pleasure related to messages. In this respect, there are games, music, and visual applications in many of mobile advertising applications [20]. The perceived entertainment value of mobile advertising is 
accepted to be one of the most important factors affecting attitudes of consumers towards advertising [15].

Irritation comprises the only negative dimension of consumer attitudes towards mobile advertising [20]. Irritation in an advertisement decreases advertisement effectiveness (Ducoffe, 1995) [2]. When advertising employs annoying techniques and are overly manipulative, customers are unlikely to perceive the advertisement as a favorable influence (Ducoffe, 1995) [2]. When people feel that advertisements are irritating or disturbing, their attitudes towards the product advertised change in a negative way [15]. Therefore, we propose the following hypothesis:

H2: Perceived informativeness of mobile advertising (PIMA) has a positive relationship with the attitude towards mobile advertisements (ATMA).

H3: Perceived entertainment of mobile advertising (PEMA) has a positive relationship with the attitude towards mobile advertisements (ATMA).

H4: Perceived irritation of mobile advertising (PIMA) has a negative relationship with the attitude towards mobile advertisements (ATMA).

\section{Mobile Advertising Usage for Getting Information}

The concepts of attitude, intention and behavior constitute three keystones of the Theory of Reasoned action developed by Fishbein and Ajzen (1975) [21]. Many studies consider attitude as one of the determinants of mobile users' behaviors. Favorable attitudes toward mobile advertising, correlated with strong reasons, lead to positive actions and intentions (Lee et al. 2009) [22]. The ultimate goal of advertising is to persuade consumers to appreciate and purchase the advertised products (Sun et al. 2010) [23]. A precondition to reach this goal is that consumers are involved and actively use mobile advertising to get information. So we conceptualize the construct mobile advertising usage for getting information (MAGI) to as the actual usage of mobile advertising for getting information with respect to the frequency of use and the amount of time involved.

According to the self-efficacy theory, self-efficacy refers to individuals' judgments of their capabilities rather than objective abilities (Yan, 2015) [24]. When people believe that their capabilities are exceeded by the task, they tend to have little incentive to undertake the task. However, if people feel confident of the desired outcomes of actions, they would perform the actions (Yan, 2015) [24]. Consequently, people's actions are based more on what they feel confident of than on what is objectively true. In this paper, we focus on self-efficacy in mobile advertising usage for getting information. We suggest if people have very strong self-efficacy, he will be very willing to find product information through the mobile web, and will easily found what he need. On the contrary, he may be reluctant to do so. We thus hypothesize:

H5: Attitude toward mobile advertising (ATMA) has a positive relationship with mobile advertising usage for getting information (MAGI).
H6: Self-efficacy has a positive relationship with mobile advertising usage for getting information (MAGI).

\section{METHOD AND DATA COLLECTION}

\section{A. Measure Development}

All the constructs (latent variables) and their corresponding measure items are adapted from the previous literature to fit the context of this study. The complete instrument can be found in Table A1 in the Appendix. All items were measured with a seven-point disagree-agree Likert scale (1 represents "strongly disagree" while 7 represents "strongly agree").

\section{B. Data Collection}

Two PhDs and eight masters took part in a pilot survey. Based on their feedback and the experiences in administering the pilot survey, wording was adjusted in several items. The large-scale survey data collection lasted for 3 weeks through an online survey website. Empirical data was mainly collected at university campuses located in Wuhan in China. Users who have had an experience viewing on smartphone advertisements were randomly invited to visit the online questionnaire and solicited their participation. The response rate was approximately $60 \%$. Invalid responses were deleted, and data collected from 197 users of smartphone advertisements were used for data analysis. Table 1 presents the demographic information of these 197 respondents.

TABLE I. DEMOGRAPHIC INFORMATION OF RESPONDENTS

\begin{tabular}{|c|c|c|c|}
\hline Measure & Item & Frequency & Percent \\
\hline Gender & Male & 80 & 40.60 \\
& Female & 117 & 59.40 \\
\hline Age & $18-25$ 岁 & 182 & 92.38 \\
& $26-35$ 岁 & 8 & 4.06 \\
& $36-45$ 岁 & 5 & 2.54 \\
& $>45$ 岁 & 2 & 1.02 \\
\hline Research field & Natural Sciences & 23 & 11.68 \\
& Social Sciences & 91 & 46.19 \\
& Arts and & 28 & 14.21 \\
& Humanities & 55 & 27.92 \\
& Others & & \\
\hline Position & Undergraduate & 177 & 89.85 \\
& Master student & 10 & 5.08 \\
& Doctoral student & 8 & 4.06 \\
& Faculty & 2 & 1.02 \\
\hline Your experience & $<1$ & 10 & 5.08 \\
with smartphone & $1-2$ & 24 & 12.18 \\
(years) & $2-3$ & 50 & 25.38 \\
& $3-4$ & 44 & 22.34 \\
& $>4$ & 69 & 35.03 \\
\hline
\end{tabular}

Since the constructs and items are all from or adapted from previous English papers, the original instrument was developed in English and then translated into Chinese. After translation, it was back-translated to English to ensure equivalence of meaning. All data were collected in Chinese and recorded in English for this paper. 


\section{DATA ANALYSIS AND RESULTS}

\section{A. Measurement Model Validation}

Partial least squares (PLS) structural equation modeling (SEM) was applied to estimate the research model in this study. Before testing the hypothesized relationships, measurement model validation was assessed in terms of content validity, convergent validity and discriminant validity (Straub, Boudreau, \& Gefen, 2004) [25]. With respect to content validity, since all the constructs and items in this study were based on the previous literature, these constructs and items are each believed to have clear and correct meaning.

AVE (average variance extracted), CR (composite reliability), and Cronbach's alpha were calculated (Table 2). Convergent validity was assessed with $\mathrm{CR}$ and Cronbach's alpha and can be established with a score greater than 0.7. AVE can also help assess convergent validity and can be established with a score greater than 0.5 (Straub et al., 2004) [41]. All the values of CR, Cronbach's alpha, and AVE exceed the threshold value, suggesting higher reliability and convergent validity of all the constructs. Also, discriminant validity was established since the square root of each construct's AVE (bold values) is larger than its correlations with other constructs (Table 3) (Straub et al., 2004) [25]. All items load much higher on their specified constructs (bold values) than on other constructs (Table 4), further suggesting sufficient discriminant and convergent validity for all the constructs (Straub et al., 2004) [25].

Given that some correlations between constructs are greater than 0.6 (Table 3 ), further diagnostics were performed to assess potential multicollinearity among the independent variables. All variables had a variance inflation factor (VIF) less than 3.2, lower than the recommended threshold of 10 (Gefen, Rigdon, \& Straub, 2011) [26]; thus, multicollinearity does not appear to be a concern

TABLE II. OVERVIEW OF MEASUREMENT MODEL

\begin{tabular}{|c|c|c|c|c|}
\hline Constructs & Items & Ave & CR & $\begin{array}{c}\text { Cronbach's } \\
\text { alpha }\end{array}$ \\
\hline $\begin{array}{c}\text { Attitude towards Mobile } \\
\text { Advertising (ATMA) }\end{array}$ & 3 & 0.817 & 0.931 & 0.888 \\
\hline $\begin{array}{c}\text { Credibility of Mobile } \\
\text { Advertising (CMA) }\end{array}$ & 3 & 0.800 & 0.923 & 0.874 \\
\hline $\begin{array}{c}\text { Perceived Entertainment of } \\
\text { Mobile Advertising } \\
\text { (PEMA) }\end{array}$ & 3 & 0.841 & 0.941 & 0.905 \\
\hline $\begin{array}{c}\text { Mobile Advertising Usage } \\
\text { for Getting Information } \\
\text { (MAGI) }\end{array}$ & 3 & 0.863 & 0.950 & 0.920 \\
\hline $\begin{array}{c}\text { Perceived Informativeness } \\
\text { of Mobile Advertising } \\
\text { (PIMA) }\end{array}$ & 3 & 0.828 & 0.935 & 0.897 \\
\hline $\begin{array}{c}\text { Perceived Irritation of } \\
\text { Mobile Advertising } \\
\text { (PIRMA) }\end{array}$ & 3 & 0.876 & 0.955 & 0.929 \\
\hline \begin{tabular}{c} 
Self-efficacy (SEfficacy) \\
\hline
\end{tabular} & 3 & 0.839 & 0.940 & 0.905 \\
\hline
\end{tabular}

TABLE III. CORRELATIONS BETWEEN CONSTRUCTS AND SQUARE ROOTS OF AVES

\begin{tabular}{|c|c|c|c|c|c|c|c|}
\hline & ATMA & CMA & PEMA & MAGI & PIMA & PIRMA & SEfficacy \\
\hline ATMA & 0.904 & & & & & & \\
\hline CMA & 0.689 & 0.894 & & & & & \\
\hline PEMA & 0.658 & 0.542 & 0.917 & & & & \\
\hline MAGI & 0.803 & 0.686 & 0.651 & 0.929 & & & \\
\hline PIMA & 0.674 & 0.614 & 0.650 & 0.608 & 0.910 & & \\
\hline PIRMA & -0.275 & -0.290 & -0.269 & -0.279 & -0.321 & 0.936 & \\
\hline SEfficacy & 0.640 & 0.497 & 0.428 & 0.591 & 0.500 & -0.193 & 0.916 \\
\hline
\end{tabular}

TABLE IV. LOADINGS AND CROSS-LOADINGS

\begin{tabular}{|c|c|c|c|c|c|c|c|}
\hline & ATMA & CMA & PEMA & MAGI & PIMA & PIRMA & SEfficacy \\
\hline ATMA1 & $\mathbf{0 . 8 9 4}$ & 0.634 & 0.562 & 0.716 & 0.642 & -0.241 & 0.608 \\
ATMA2 & $\mathbf{0 . 9 1 9}$ & 0.583 & 0.562 & 0.708 & 0.619 & -0.248 & 0.591 \\
ATMA3 & $\mathbf{0 . 8 9 8}$ & 0.649 & 0.657 & 0.751 & 0.568 & -0.255 & 0.539 \\
\hline CMA1 & 0.649 & $\mathbf{0 . 8 7 2}$ & 0.477 & 0.630 & 0.577 & -0.215 & 0.523 \\
CMA2 & 0.645 & $\mathbf{0 . 9 4 2}$ & 0.481 & 0.630 & 0.570 & -0.262 & 0.447 \\
CMA3 & 0.546 & $\mathbf{0 . 8 6 7}$ & 0.501 & 0.576 & 0.493 & -0.310 & 0.349 \\
\hline PEMA1 & 0.597 & 0.454 & $\mathbf{0 . 8 8 8}$ & 0.568 & 0.682 & -0.237 & 0.392 \\
PEMA2 & 0.636 & 0.555 & $\mathbf{0 . 9 5 0}$ & 0.633 & 0.578 & -0.273 & 0.414 \\
PEMA3 & 0.576 & 0.480 & $\mathbf{0 . 9 1 2}$ & 0.588 & 0.528 & -0.229 & 0.368 \\
\hline MAGI1 & 0.757 & 0.649 & 0.596 & $\mathbf{0 . 9 2 2}$ & 0.629 & -0.233 & 0.567 \\
MAGI2 & 0.756 & 0.623 & 0.584 & $\mathbf{0 . 9 4 6}$ & 0.517 & -0.260 & 0.530 \\
MAGI3 & 0.722 & 0.640 & 0.636 & $\mathbf{0 . 9 1 8}$ & 0.547 & -0.285 & 0.551 \\
\hline PIMA1 & 0.565 & 0.432 & 0.527 & 0.469 & $\mathbf{0 . 8 9 9}$ & -0.223 & 0.427 \\
PIMA2 & 0.590 & 0.534 & 0.610 & 0.515 & $\mathbf{0 . 9 2 6}$ & -0.305 & 0.461 \\
PIMA3 & 0.674 & 0.687 & 0.628 & 0.657 & $\mathbf{0 . 9 0 6}$ & -0.338 & 0.473 \\
\hline PIRMA1 & -0.282 & -0.284 & -0.279 & -0.297 & -0.311 & $\mathbf{0 . 9 4 5}$ & -0.176 \\
PIRMA2 & -0.238 & -0.286 & -0.226 & -0.253 & -0.275 & $\mathbf{0 . 9 3 9}$ & -0.183 \\
PIRMA3 & -0.248 & -0.243 & -0.247 & -0.229 & -0.313 & $\mathbf{0 . 9 2 5}$ & -0.185 \\
\hline SEfficacy1 & 0.643 & 0.522 & 0.422 & 0.592 & 0.499 & -0.211 & $\mathbf{0 . 9 3 0}$ \\
\hline SEfficacy2 & 0.606 & 0.468 & 0.422 & 0.574 & 0.473 & -0.202 & $\mathbf{0 . 9 4 5}$ \\
\hline PEficacy3 & 0.493 & 0.354 & 0.317 & 0.440 & 0.387 & -0.101 & $\mathbf{0 . 8 7 2}$ \\
\hline
\end{tabular}

\section{B. Common Method Bias}

The influence of common method bias resulting from multiple sources such as social desirability has been a wide concern in the behavioral sciences (Liang, Saraf, Hu, \& Xue, 2007) [27]. Obtaining data from different sources can help reduce common method variance (CMV), and Harman's singlefactor test is arguably the most extensively applied approach for assessing CMV (Podsakoff et al., 2003) [28]. The data in this study were collected from different sources, which is helpful for reducing CMV. Harman's single-factor test was performed by conducting a principal components analysis 
(PCA) in SPSS. The first factor accounted for $19.981 \%$ of the variance, indicating that this factor does not account for the majority of the variance.

Furthermore, following Liang et al. (2007) [29], this study included in the PLS model a common method factor whose indicators included all the principal constructs' indicators. For each single-indicator construct, the coefficients of its two incoming paths from its substantive construct and the method factor were examined (Liang et al., 2007) [29]. Most method path coefficients are not significant. The path coefficients of substantive constructs are substantially greater than their method path coefficients, thus explaining substantially greater variance of items than method. It is thus reasonable to contend that common method bias is not a concern in this study.

\section{Structural Model with Results}

The structural model with results is presented in Fig. 2 . Tests of significance were performed using the bootstrap resampling procedure with 1000 samples, following the recommendation that the sample size should be at least 500 (Wetzels, Odekerken-Schroder, \& van Oppen, 2009) [30], so as to obtain the $t$ values of the estimates. The explained variances of attitude towards mobile advertising and mobile advertising usage for getting information are 0.621 and 0.654 , respectively, showing very good predictive validity of the model (Straub et al., 2004) [25].
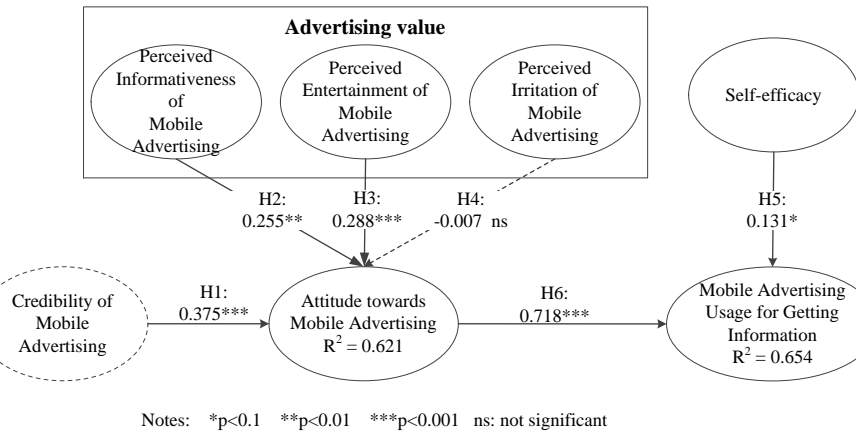

Fig. 2. PLS structural model with results.

TABLE V. SUMMARY OF PLS RESULTS

\begin{tabular}{|l|c|c|}
\hline \multicolumn{1}{|c|}{ Hypothese } & Path coefficients & Results \\
\hline H1: CMA $\rightarrow$ ATMA & $0.375^{* * *}$ & Supported \\
\hline H2: PIMA $\rightarrow$ ATMA & $0.255^{* *}$ & Supported \\
\hline H3: PEMA $\rightarrow$ ATMA & $0.288^{* * *}$ & Supported \\
\hline H4: PIRMA $\rightarrow$ ATMA & -0.007 & Not Supported \\
\hline H5: SEfficacy $\rightarrow$ MAGI & $0.131 *$ & Supported \\
\hline H6: ATMA $\rightarrow$ MAGI & $0.718 * * *$ & Supported \\
\hline
\end{tabular}

As shown in Figure 2, credibility has significant effect on attitude towards mobile advertising, thus, H1 is supported. For the impact of advertising value on attitude towards mobile advertising, only the effect of Irritation is not significant; thus, $\mathrm{H} 4$ is not supported while $\mathrm{H} 2$ and $\mathrm{H} 3$ are supported. Attitude towards mobile advertising has the largest effect on mobile advertising usage for getting information, thus, H6 is supported. Meanwhile, self-efficacy also has significant effect on mobile advertising usage for getting information, thus, H5 is supported. Table 5 is a summary of the results.

\section{CONCLUSION}

\section{A. Implications for Theory}

There are several theoretical contributions from this study. First, the study explored the impact of consumers' attitude towards mobile advertising on their online information acquisition behavior. Although Ducoffe et al. (1995) [2] and Sun et al. (2010) [31] has extensively explored advertising value as antecedents of attitude towards advertising, previous studies have not paid attention in examining the relationships between consumers' attitude towards mobile advertising and their online information acquisition behavior. Thus, the results of this study extend the current literature on mobile advertising. Second, this study offers empirical evidence that credibility is the most critical predictor of the formation of consumers' attitude towards mobile advertising. Third, this study discloses the role of self-efficacy that increases mobile advertising usage for getting information. Very few studies from a mobile advertising context have investigated the role of self-efficacy in product information acquirement behavior from mobile web. We believe that the current research usefully contributes to the theoretical development of the structural model exploring the effectiveness of mobile advertising in the specific context of China and beyond more generally.

\section{B. Implications for Practice}

From a practical perspective, marketers and advertisers will gain insight on how mobile advertising contribute to stimulate customers' interesting in searching for search product information which will further forms customer purchase intention. Our model results provide some strategic and managerial guidelines to marketers, advertisers, and mobile advertising platform providers. Marketers and advertisers are better off to deliver more pleasant and informative mobile advertisings to customers while giving up a spray advertising approach that causes irritation of customers. Web advertisers can offer more specific, definite and tangible facts about products on the website to help online consumers evaluate alternatives and use rich media and video advertising formats to attract consumers to get product information (Bruner 2006) [32]. In our study, credibility is a most important element of forming a positive attitude towards mobile advertising. Thus, marketers and advertisers should make every effort to create and disseminate true and reliable product information while eliminating false and exaggerated advertising information.

\section{Limitations and Future Research}

This study has its limitations. First, the survey population is confined to China. Further research is required to generalize the research model to other cultural and country contexts. Second, there are four antecedents or dimensions of advertisement credibility (MacKenzie and Lutz, 1989) [7] that might facilitate the formation of web advertising credibility. 
Future research should examine other factors that affect mobile advertising credibility.

\section{REFERENCES}

[1] Lutz, B. J., S. B. MacKenzie, and G. E. Belch. 1983. "Attitude Toward the Ad as a Mediator of Advertising Effectiveness: Determinants and Consequences." In NA - Advances in Consumer Research, edited by R. agozzi, A. Tybout, and A.Abor, 532-539. Ann Abor, MI: Association for Consumer Research.

[2] Ducoffe, R. H. (1995). How consumers assess the value of advertising. Journal of Current Issues and Research in Advertising, 17(1), 1-18

[3] Blanco, C. F., Blasco, M. G., \& Azorin, I. I. (2010). Entertainment and informativeness as precursory factors of successful mobile advertising messages. Communications of the IBIMA, 1-11.

[4] Aaker, D. A., \& Norris, D. (1982). Characteristics of TV commercials perceived as informative. Journal of Advertising Research, 22(2), 61-70.

[5] McQuail, D. (2005). Mass communication theory (5th ed.). London Sage. Milne, G. R., \& Gordon, M. E. (1993). Direct mail privacyefficiency trade-offs within an implied social contract framework. Journal of Public Policy and Marketing, 12(2), 206-215.

[6] Aaker, D. A., \& Bruzzone, D. E. (1985). Causes of irritation in advertising. Journal of Marketing, 49(2), 47-57.

[7] MacKenzie, S. B., \& Lutz, R. J. (1989). An empirical examination of the structural antecedents of attitude toward the ad in an advertising pretesting context. Journal of Marketing, 53(2), 48-65.

[8] Goldfarb, A., and C. Tucker. 2011. "Substitution Between Offline and Online Advertising Markets." Journal of Competition Law \& Economics 7 (1): 37-44.

[9] McKnight, H., and C. Kacmar. 2006. "Factors of Information Credibility for an Internet Advice Site." Proceedings of the 39th Hawail International Conference on System Sciences, Kauai, Hawaii, January 4-

[10] Wong, Mandy M.T. and Tang, Esther P.Y. (2008), Consumers' Attitudes Towards Mobile Advertising: The Role of Permission, Review of Business Research, 8, 3, pp.181-187.

[11] Bandura A (1977) Self-efficacy: Toward a unifying theory of behavioral change. Psychological Review 84(2): 191-215

[12] Bandura A (1982) Self-efficacy mechanism in human agency. American Psychologist 37(2): 122-147.

[13] Ren WH (2000) Library instruction and college student self-efficacy in electronic information searching. The Journal of Academic Librarianship 26(5): 323-328.

[14] Pavlou PA and Fygenson M(2006) Understanding and predicting electronic commerce adoption: an extension of the theory of planned behavior. MIS Quarterly 30(1): 115-143.

[15] Choi, S. M., and N. J. Rifon. 2002. "Antecedents and Consequences of Web Advertising Credibility: A Study of Consumer Response to Banner Ads." Journal of Interactive Advertising 3 (1): 12-24.

[16] Lafferty, B. A., and R. E. Goldsmith. 1999. "Corporate Credibility's Role in Consumers' Attitudes and Purchase Intentions When a High Versus a Low Credibility Endorser is Used in the Ad." Journal of Business Research 44 (2): 109-116.
[17] Haghirian, P., M. Madlberger, and A. Tanuskova. 2005. "Increasing Advertising Value of Mobile Marketing - An Empirical Study of Antecedents." Paper presented at the 38th Hawaii International Conference on System Sciences, Big Island, HI.

[18] Bauer, R.A. and Greyser, S.A. (1968) Advertising in America: The Consumer View. Boston, Massachusetts: Division of Research, Graduate School of Business Administration, Harvard University.

[19] Pollay, R.W. and Mittal, B. (1993), "Here's the beef: factors, determinants and segments in consumer criticism of advertising", Journal of Marketing, Vol. 57 No. 3, pp. 99-114.

[20] Hoffman, D.L. and Novak, T.P. (1996), "Marketing in hypermedia computer mediated environments: conceptual foundations", Journal of Marketing, Vol. 60 No. 3, pp. 50-68.

[21] Fishbein, M., and I. Ajzen. 1975. Belief, Attitude, Intention, and Behavior: An Introduction to Theory and Research. Boston, MA: Addison-Wesley.

[22] Lee, C. C., and M. C. Hsieh. 2009. "The Influence of Mobile SelfEfficacy on Attitude towards Mobile Advertising." Paper presented at the International Conference on New Trends in Information and Service Science, Beijing, China

[23] Sun, Y. Q., K. H. Lim, C. P. Jiang, J. Z. Peng, and X. J. Chen. 2010 "Do Males and Females Think in the Same Way? An Empirical Investigation on the Gender Differences in Web Advertising Evaluation." Computers in Human Behavior 26 (6): 1614-1624.

[24] Yan, Y., et al. (2015). "Exploring the effect of individual differences on self-efficacy in getting information." Information Development 32(4): 1097-1108.

[25] Straub, D. W., M. C. Boudreau, and D. Gefen. 2004. "Validation Guidelines for IS Positivist Research." Communications of the Association for Information Systems 13 (1): 380-427.

[26] Gefen, D., E. E. Rigdon, and D. Straub. 2011. "An Update and Extension to SEM Guidelines for Administrative and Social Science Research.” MIS Quarterly 35 (2): ii-xiv.

[27] Liang, H. G., N. Saraf, Q. Hu and Y. J. Xue. 2007. "Assimilation of Enterprise Systems: The Effect of Institutional Pressures and the Mediating Role of Top Management.” MIS Quarterly 31 (1): 59-87.

[28] Podsakoff, P. M., S. B. MacKenzie, J. Y. Lee, and N. P. Podsakoff. 2003. "Common Method Biases in Behavioral Research: A Critical Review of the Literature and Recommended Remedies." Journal of Applied Psychology 88 (5): 879-903.

[29] Liang, H. G., N. Saraf, Q. Hu and Y. J. Xue. 2007. "Assimilation of Enterprise Systems: The Effect of Institutional Pressures and the Mediating Role of Top Management.” MIS Quarterly 31 (1): 59-87.

[30] Wetzels, M., G. O. Schroder, and V. C. Oppen. 2009. "Using PLS Path Modeling for Assessing Hierarchical Construct Models: Guidelines and Empirical Illustration.” MIS Quarterly 33 (1): 177-195.

[31] Sun, Y. Q., K. H. Lim, C. P. Jiang, J. Z. Peng, and X. J. Chen. 2010 "Do Males and Females Think in the Same Way? An Empirical Investigation on the Gender Differences in Web Advertising Evaluation." Computers in Human Behavior 26 (6): 1614-1624.

[32] Bruner, R. E. 2006. "Best Practices for OptimizingWeb Advertising Effectiveness [online]." Accessed March 3, 2012. http://www.doubleclick.com. 